Int. J. Odontostomat.,

4(3):229-236, 2010.

\title{
Evaluation of Different Post Systems: Finite Element Method
}

\author{
Evaluación de Diferentes Sistemas de Postes: Método de Elementos Finitos
}

Laura Bessone \& Enrique Fernandez Bodereau Jr.

\begin{abstract}
BESSONE, L. \& FERNANDEZ B. E. Jr. Evaluation of different post systems: finite element method. Int. J. Odontostomat., 4(3):229-236, 2010.

ABSTRACT: The aim of this study was to analyse the stress distribution in maxillary canines restored with different post systems and definitive crowns. The models of restored teeth with glass fiber, quartz fiber, titanium posts and crowns were developed with the Finite Element Method (FEM) in order to analyse their stress distribution when subjected to external compressive loads. Von Mises stress distribution values, which are considered potential fracture indicator, showed that natural tooth and glass fiber post-restored tooth, under a load of $550 \mathrm{~N}$, presented similar stress values. The behaviour of a glass fiber post-restored tooth is similar to that of a natural tooth, since it produces an appropriate stress distribution, and in this investigation, they have the best biomechanical performance.
\end{abstract}

KEY WORDS: glass fiber post, quartz fiber post, stress distribution, finite element method.

\section{INTRODUCTION}

Restorative methods for pulpless teeth with postcore systems have been widely investigated with the aim of achieving long-term promising prognosis (Hayashi et al., 2006).

Some of the reasons for the failure of restorations for many years have been root fracture, microleakage, decementation, and metal corrosion in clinical practice (Reeh et al., 1989). Some of the fractures affecting post restorations could be related to concentration of forces (Sorrentino et al., 2007).

In recent years, various types of fiber posts have been introduced and excellent long term clinical performances of pulpless teeth restored with a combination of fiber posts and resin in conjunction with dentin bonding systems were reported (Li et al., 2006; Pierrisnard et al., 2002; Holmes et al., 1996; Zienkiewics, 1986; Torsavul et al., 2006).

As is well-known, loads are produced during all the functions of the oral cavity. The average maximum bite force in human was measured at $911 \mathrm{~N}$ (Newtons) in the molar region and at $569 \mathrm{~N}$ in the incisal region (Craig, 1980).These forces applied to the dental restoration materials are a potencial cause of deformations due to the dimensional changes (lengths, volumes) they produce in most of the cases (Craig).

Recent Finite Element Analyses presented the different stress distributions in pulpless teeth restored with different post core systems (Zarone et al., 2006; Eskitas, clog lu et al., 2002). Searching the literature, the majority of papers based on FE modelling of stress distributon in post and crown restored teeth is based on two dimensional (2D) models (Schillinburg \& Kessler, 1982; Zarone et al.) and only few on three dimensional (3D) ones (Toksavul et al.; Mannocci et al., 1999; Malferrari et al., 2003).

For the purpose of making a comparison between the behaviours of natural healthy teeth and restored teeth subjected to different loads, the FEM (Finite Element Method) was applied in this study.

Through the FEM, it is possible to design a mathematical 3D model that simulates the geometry and load conditions of the structure under analysis. It facilitates the evaluation of deformation and stress behaviours at some point of the model and it can also 
determine high deformation or stress concentration areas (Pierrisnard et al.).

The aim of this study was, by using the finite element method, to make an analysis of stress distribution under different load levels applied to healthy maxillary canines and to others restored with different post systems and definitive crowns.

\section{MATERIAL AND METHOD}

The methodology developed for this study was based on the creation of finite element models. Through the implementation of FEM, different load values were applied and stress distribution was observed in each model (Li et al.; Pierrisnard et al.; De Jager et al., 2006; Pegoretti et al., 2002).

Four finite element models were predesigned with CATIA, a CAD software. Three-dimensional solid geometric models were generated from healthy maxillary canines and canines with alternatives of restorative treatment (Table I). These treatments included a titanium post, a glass fiber post and a quartz fiber post, all of them with resin cores and ceramic crowns (Fig.1) (feldspathic all-ceramic crown).

Through the import of the CATIA geometry into a mesh-generating program called ABAQUS/CAE, Version 6.4 (USA, 2003), four finite element models and three submodels were built. Tetrahedrons, thus, had to be formed from 4-node solid elements and hexaedrons from 8-node solid elements.

The restorative material properties like density, elastic modulus, plastic behaviour curve, and the characteristics of the forces to apply were simulated as well as the components of the finite element models and submodels: dentine, enamel, cement, feldespathicceramic crown, post, core and cancellous bone support (table II). The gutta-percha and the periodontal ligament were not included in the models because they would not influence the results significantly

In relation to the comparative nature of the structural evaluations, the following arbitrary commercially available post geometry was used:

- $1.5 \mathrm{~mm}$ diameter.

- $10 \mathrm{~mm}$ insertion depth (about two thirds of the root length).

- $3 \mathrm{~mm}$ coronal tissue over the cement-enamel junction (CEJ).

- $1.5 \mathrm{~mm}$-thick vestibular and proximal surface.

. $1.2 \mathrm{~mm}$-thick palatal surface.

- $2 \mathrm{~mm}$-thick incisal surface.

. $7 \mathrm{~mm}$ length abutments.

Other characteristics to introduce are the Poisson's ratios which define the relation between deformations of the material in the longitudinal direction of the applied load and also in transversal directions (Mannocci et al.).

Some of the restorative materials used in this study were isotropic and others anisotropic. Table II shows the elastic modulus and the Poisson's ratio for isotropic materials. Table III shows the values of the independent elastic constants, i.e., the elastic modulus in longitudinal and transverse directions, and the Poisson's ratio for anisotropic materials. For example, the titanium are assumed to be an isotropic material because their properties are measured in any direction and the results obtained are identical (Malferrari et al., 2003). In the case of glass fiber post, their properties can also be measured, but the results obtained vary according to the direction in which they are measured or observed.

Table I. Experimental models.

\begin{tabular}{lcc}
\hline \multicolumn{1}{c}{ Material/ component } & Young Moduli (Mpa) & Poisson's coefficient \\
\hline Dentine & 18000 & 0.31 \\
Bone & 1370 & 0.30 \\
Ceramic crown & 69000 & 0.28 \\
Titanium post & 103400 & 0.33 \\
Resin & 18530 & 0.28 \\
Enamel & 41000 & 0.30 \\
Cement & 2700 & 0.30 \\
\hline
\end{tabular}




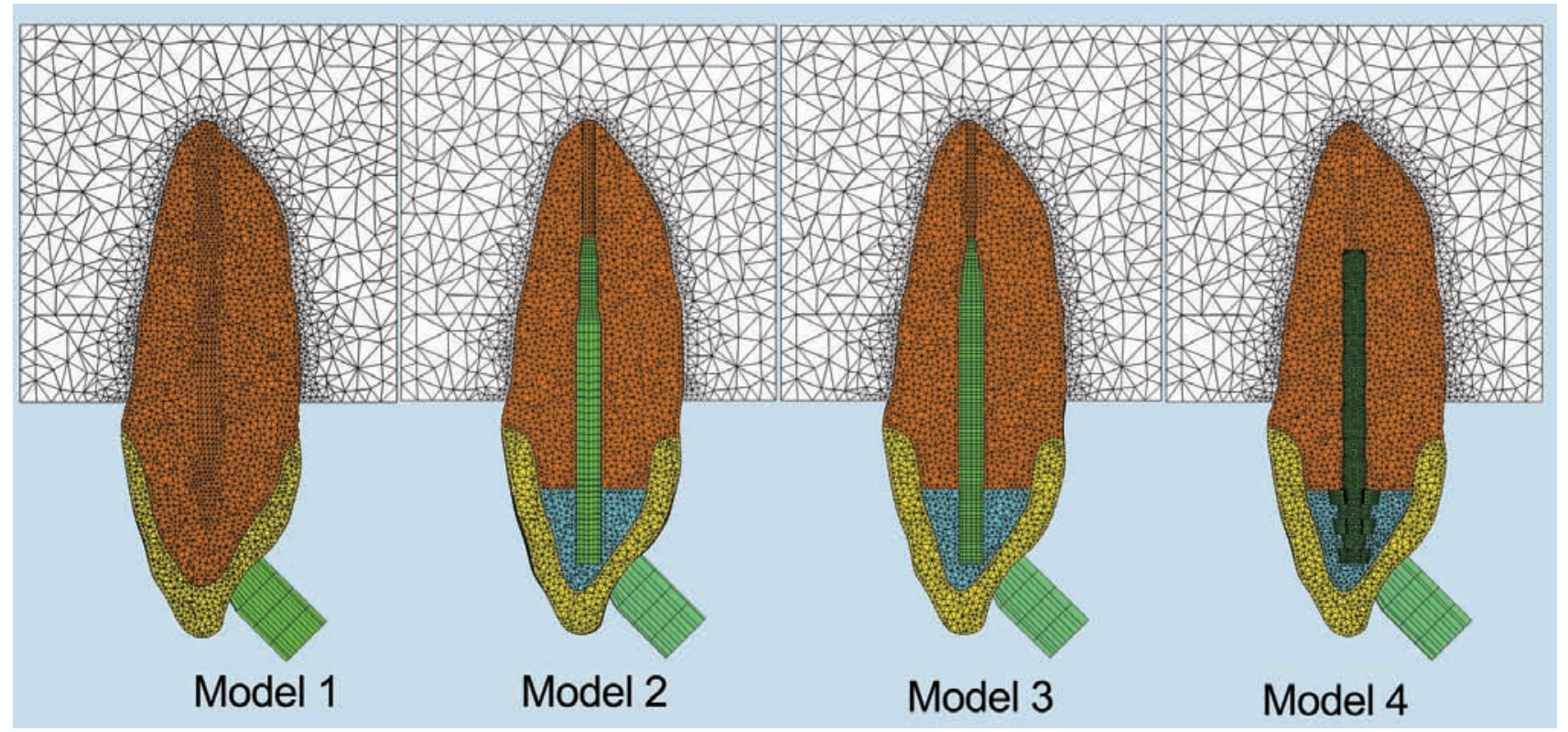

Fig. 1. Finite element models. Note the reproduction of all its components including the alveolar bone. Model $1:$ natural teeth (maxillary canine). Model 2: finite element model of teeth restored with quartz fiber post. Model 3: a finite element model of teeth restored with glass fiber post. Model 4: finite element model of teeth restored with titanium posts; all of them have porcelain crowns.

Loading conditions. In order to apply the loads over the canines, a $3 \mathrm{~mm}$ cylinder was used. The compressive loads were applied at 45 degrees with respect to its longitudinal axis, at the level of the cingulum (middle third of the palatal surface) simulating the load conditions in the oral cavity.

A progressive and compressive non-destructive load was initially applied over the teeth in order to detach the crown from the core of restorations but without producing other visible damages. In this way, we observed the changes in the crown margin of the analysed models.

The submodel technique was implemented and three submodels were developed with a greater number of finite elements, namely with a more dense mesh. The reasons for the application of this technique were the analysis of specific areas of the models, and the observation of changes produced when a nondestructive load was applied in that specific area: the crown margin (Fig. 2).A second progressive and compressive load was applied to all the finite element models (both healthy and restored ones) until the dentine fracture occured.

The analysis of the results was made considering Von Mises criterion for three dimensional stresses. Von Mises stresses indicate the presence of localized high stress areas, but it is not possible to determine the nature of such stresses (traction or compression). (De Jager et al.). A selection of pure traction stresses (S33) was made, like in other studies (Ko et al., 1992; BarjauEscribano et al., 2006), because the fracture of dentine could be due to traction, so, these stresses could be also responsible for cracks.

Table II. Elastic properties of the isotropic materials.

\begin{tabular}{cccc}
\hline Models & Crown & Core & Post/cement \\
\hline 1 & $\begin{array}{c}\text { Natural tooth } \\
\text { Feldspathic ceramics }\end{array}$ & $\begin{array}{c}\text { Natural tooth } \\
\text { Enforce core(resin core) }\end{array}$ & $\begin{array}{c}\text { Quartz fiber post (BISCO)/ } \\
\text { C\&B resin cement (BISCO) }\end{array}$ \\
3 & Feldspathic ceramics & Enforce core(resin core) & $\begin{array}{l}\text { Glass fiber post } \\
(\text { GLASSIX,NORDIN)/ C\&B } \\
\text { resin cement (BISCO) } \\
4\end{array}$ \\
& Feldspathic ceramics & Enforce core(resin core) & Titanium post (KOMET)/ \\
& & & C\&B resin cement (BISCO)
\end{tabular}


BESSONE, L. \& FERNANDEZ B. E. Jr. Evaluation of different post systems: finite element method. Int. J. Odontostomat., 4(3):229-236, 2010.

Table III. Anisotropic properties of the posts.

\begin{tabular}{lcc}
\hline \multicolumn{1}{c}{$\begin{array}{c}\text { Elastic moduli (E: Mpa), Shear moduli (G) and } \\
\text { Poisson's ratio(n) }\end{array}$} & Post Material \\
\hline E11: longitudinal modulus of elasticity (MPa) & 40000 & 48200 \\
E22: longitudinal modulus of elasticity (MPa) & 11000 & 8200 \\
E33: longitudinal modulus of elasticity (MPa) & 11000 & 8200 \\
G12: cross-sectional modulus of elasticity(MPa) & 4200 & 3000 \\
G13: cross-sectional modulus of elasticity (MPa) & 4200 & 3000 \\
G23: cross-sectional modulus of elasticity (MPa) & 4100 & 1300 \\
n12: Poisson's coefficient & 0.26 & 0.32 \\
n23: Posson's coefficient & 0.26 & 0.32 \\
n13: Poisson's coefficient & 0.32 & 0.4 \\
\hline
\end{tabular}

\section{RESULTS}

Figure 3 (a, b, c, d) shows the stress (S33) distribution in every finite element model analysed. After the load application in the fiber post systems, a higher stress (S33) concentration was detected at the level of the crown cervical margin, almost at the junction with the alveolar bone.

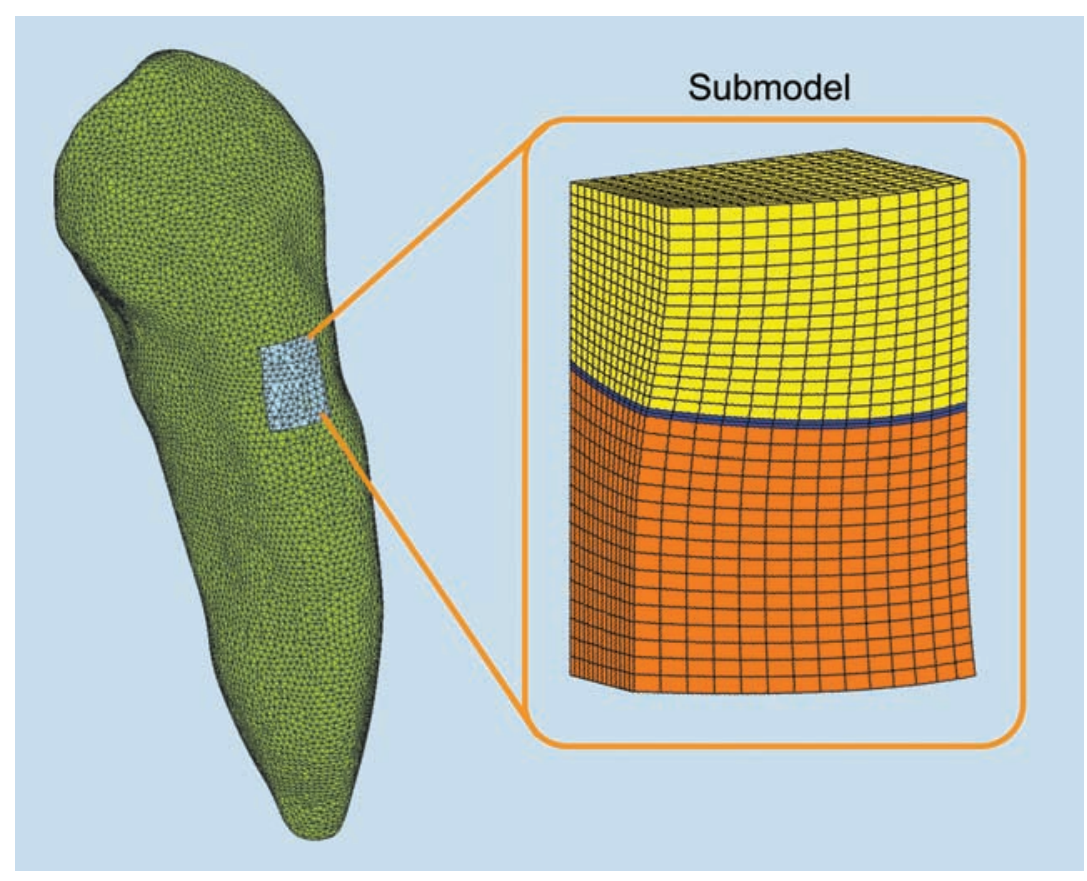

Fig. 2. Submodel of crown margin.
Figure 4 shows the stress concentration inside the posts as a result of a compressive load greater than $550 \mathrm{~N}$ applied to posts. The titanium post absorbed a greater stress while the glass fiber post showed low stress concentration.

Figure 5 shows the load levels applied on the finite element models in order to generate restoration displacement and detachment of the crown.Fiber post-restored teeth required a greater load $(490 \mathrm{~N})$ compared to metal post-restored teeth $(420 \mathrm{~N})$.

Figure 6 shows the Von Mises stress distribution values, which are considered potential fracture indicators. Model 1 (natural tooth) and model 3 (glass fiber post- 


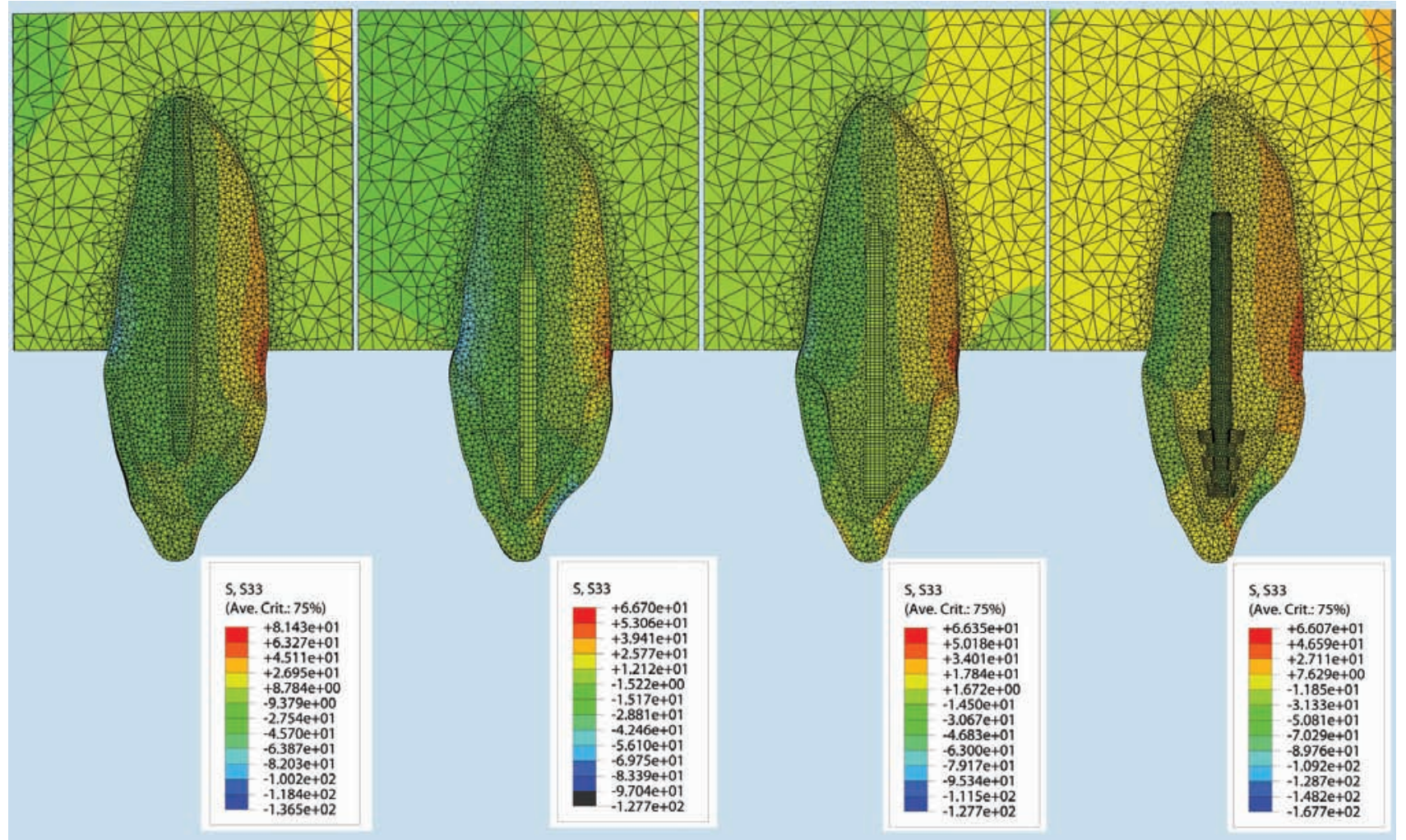

Fig. 3. Stress (S33) distribution of model 3a (natural teeth), model 3b (quartz fiber post), model 3c (glass fiber post), and model 3d (titanium post).

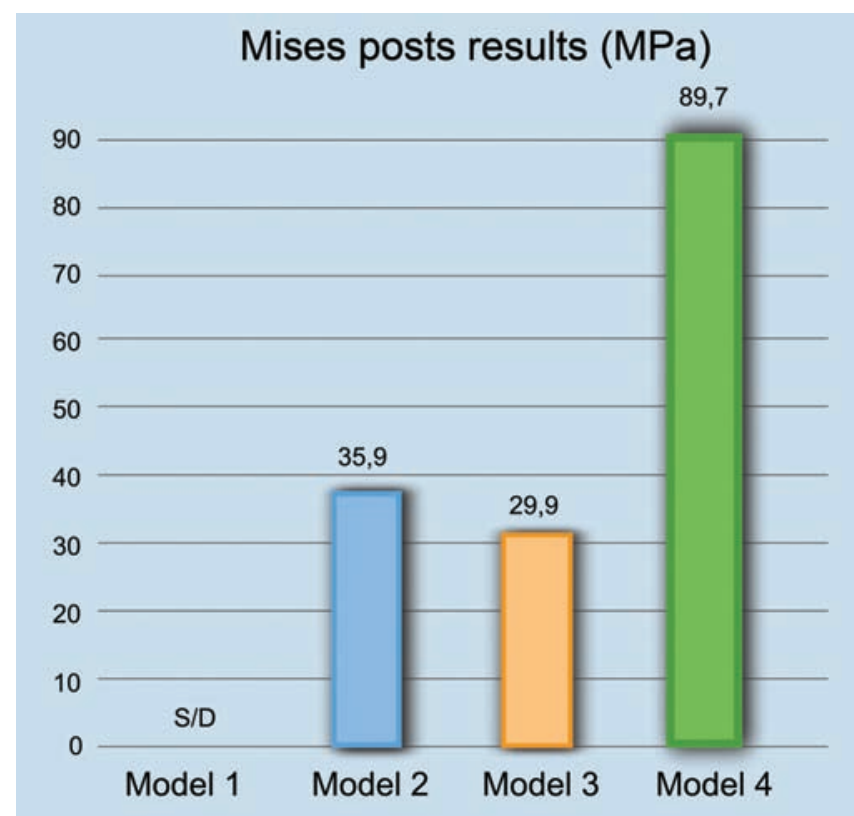

Fig. 4. Titanium posts absorb more stresses than other posts. They do not dissipate them uniformly over the other system components (cement-dentine).

restored tooth) under a load of $550 \mathrm{~N}$ showed similar stress values.
The static compressive force that was applied to overcome the fracture resistance of the restored teeth, produced stresses of vestibular compression and palatal traction at the junction with the alveolar bone. When the load was applied, vestibular compression reached values distant from a 297 MPa compressive strength of dentine. This indicated that samples were not fractured by compression, but by palatal traction that overcome a $85 \mathrm{MPa}$ tensile strenght of healthy dentine. Therefore, the palatal traction was responsible for initiating the dentine fracture.

Figure 7 shows a comparison between the stress (S33) distribution values in finite element models. Stresses S33 were traction stresses detected in the palatine area of the tooth at the cervical level.

Stresses in the natural tooth and in the glass fiber post model were similar and lower than in the other two models. The tensile strength measured in the dentin was $85 \mathrm{Mpa}$, and similar values were obtained in model 2 (quartz fiber posts) and model 4 (titanium posts). Therefore, it is deduced that quartz fiber and titanium post restored teeth are fractured earlier than natural teeth and glass fiber restored teeth. 


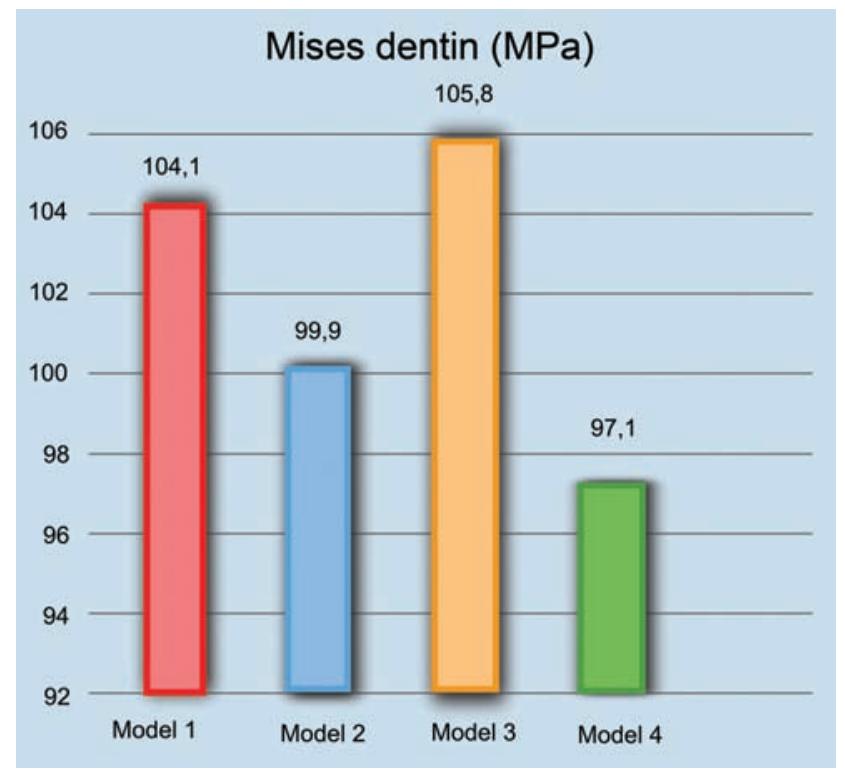

Fig. 5. The Von Mises stresses, potential fracture indicators, under a load of $550 \mathrm{~N}$ show similar values for model 1 and model 3 .

\section{Compressive Stress (N)}

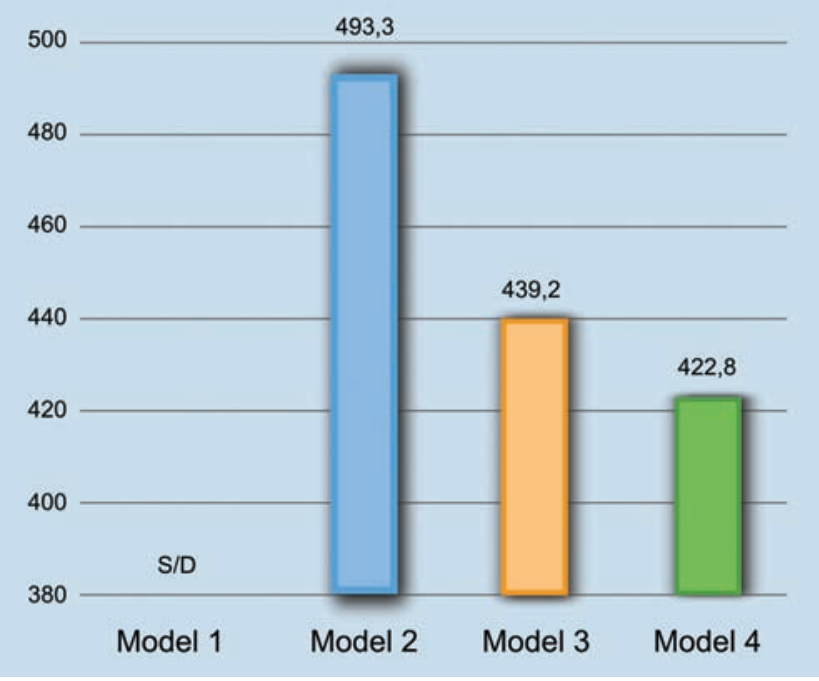

Fig. 6. FEM shows that a load of $493.3 \mathrm{~N}$ is needed to overcome the adhesive resistance of the cement joining the crown to the tooth in the models with quartz fiber posts; a load of $439.2 \mathrm{~N}$ in glass fiber posts, and a load of $422.8 \mathrm{~N}$ in titanium posts, without causing visible changes.

\section{DISCUSSION}

Every structural and design analysis of the finite element models requires full knowledge not only of the forces to be applied, but also of the mechanical properties

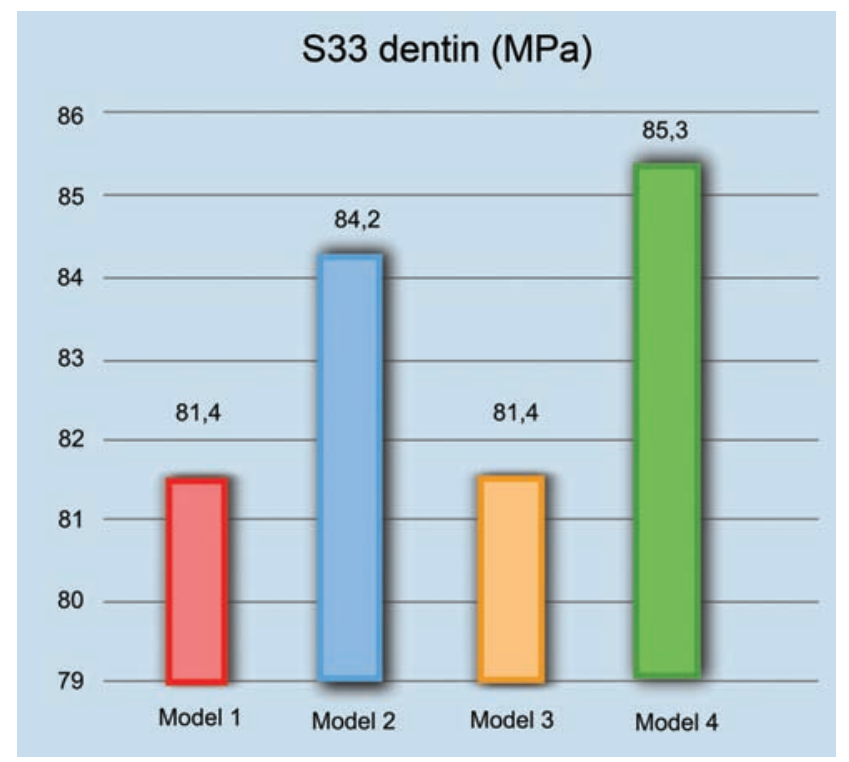

Fig. 7. Stresses S33 are traction stresses that occur in the palatal cervical area. They are similar in the natural tooth and in the glass fiber post, but lower in the other two models.

of the materials to be subjected to those forces. In oral rehabilitation, this is difficult because of the complex loads that are produced in the oral cavity, as well as the oral tissue response (Toksavul et al.).

According to the results of the present study, fiber post systems produced stress concentration at the level of the crown cervical margin, almost at the junction with the alveolar bone (CEJ). This may be due to the relatively lower Young's modulus of the material of the core, compared to that of the surrounding materials, for example, porcelain used in the crown. Since metal posts have a stiffness similar to that of the crown material, the cervical area showed less stress (Toksavul et al.).

As regards the stress concentration generated within posts under a compressive load of $550 \mathrm{~N}$, this study proved that not only a greater stress area exists at the junction of the middle and apical third of the post and tooth producing fractures at that level, but also the titanium post absorbs the greatest stress.

Moreover, the lowest stress concentration was proved in the glass fiber post model, which may result in failures in the interface (post-cement-dentine), as stated by other studies (Toksavul et al.; Eskitas, clog lu et al.).

Eraslan et al. (2009) studied and compared the stress distribution of dentine and the restoration-tooth complex, using the FEM. Three-dimensional finite element simulating an endodontically treated maxillary 
central incisor restored with an all-ceramic crown were prepared. At rigid zirconium oxide ceramic post system, stress levels, both at dentine wall and within the post, were higher than that of fiber posts. As can be seen, the results of those recent studies coincide with the observations of this work.

In this study, the applied static compressive force of $550 \mathrm{~N}$ produced vestibular compression and palatal traction stresses at the level of the junction with the alveolar bone. The vestibular compression was not sufficient to overcome the fracture resistance of samples. In this regard, it is concluded that palatal traction generated in the FEM models was responsible for the tooth fracture at that level.

The behaviour of a fiber post restored tooth was similar to that of a natural tooth since it produces an homogeneus stress distribution. On the contrary, the metal post system concentrated stresses that not only affected the interface post-cement, but also produced the tooth fracture.

Pegoretti et al. used the FEM in a study and observed that glass fiber posts restored tooth showed a low stress concentration inside the root, in comparison with metal and carbon fiber posts restored tooth (Pegoretti et al.). The greater the difference is between the Young's modulus of the dentine and the posts, the less homogenous is the stress distribution on the dental surface, and thus stress concentration areas are produced on the dentine.

Through the finite element analysis, Lanza et al. compared carbon, quartz and steel posts (Lanza et al.), appling a $10 \mathrm{~N}$ force on 125 maxillary incisors. It turned out that the steel post ( $E=200 \mathrm{GPa}$ ) transmitted most of the stress to the root, the quartz post transmitted the least stress, and the carbon post was close to the quartz post. Their results were similar to those of this study.

Other authors like Adanir et al. (2008), in a recent investigation evaluated the effects of different post materials on the stress distribution in an endodontically treated maxillary incisor using a three-dimensional finite element model of a maxillary central incisor that was modified according to five posts with different physical properties consisting of stainless steel, titanium, gold alloy, glass fiber (Snowpost), and carbon fiber (Composipost). Under different loading conditions, posts made of Metallic posts showed greater stress concentration at the post-dentine interface than fiber posts. However, fiber posts produced the highest stress values at the level of one-third of the cervical area of the crown. Their conclusion was that the physical characteristics of posts were important on stress distributions. Glass fiber post revealed more balanced stress distribution under compressive loads.

The finite element analysis method is a technique that uses computer-based simulations and that allows the calculation of stress distribution on complex structures. The validity of the study depends on the approximation to the clinical reality of the observed model. Several authors through in vitro experiments have proved the validity of the finite element analysis as the approximate procedure for predicting the biomechanical and clinical behaviour of post-restored teeth (Ko et al.; Eraslan et al.).

\section{CONCLUSIONS}

Within the limitation of this study we concluded that:

- Quartz fiber post-restored models require a greater compressive load to generate minimum displacements, to detach crowns, and more specifically, to lead to the restoration failure.

- Posts affect the load distribution in the dentine, a fact that is directly related to their modulus of elasticity.

- The method proved that the behaviour of fiber posts is similar to that of natural teeth because the stress distribution produced over their components is uniform, unlike systems restored with metal posts.

- The dentine fracture initiation load in every analysed model was determined to be $550 \mathrm{~N}$.

- The behaviour of a glass fiber post-restored tooth is similar to that of a natural tooth, since it produces an appropriate stress distribution, and in this investigation, they have the best biomechanical performance.

BESSONE, L. \& FERNANDEZ B. E. Jr. Evaluación de diferentes sistemas de postes:método de elementos finitos. Int. J. Odontostomat., 4(3):239-236, 2010.

RESUMEN: El próposito de este estudio fue analizar la distribución de tensiones en caninos superiores restaurados con diferentes sistemas de postes y coronas definitivas. Los modelos de dientes restaurados con postes defibra de vidrio, fibra de cuarzo y titanio y coronas fueron desarrollados con el Método de Elementos Finitos (FEM) para analizar la distribución de tensiones cuando fueron sometidos a cargas compresivas externas. Valores de distribución de stress de Von Mises, que fueron considerados como potenciales indicadores de fracturas, mostraron que los dientes naturales, y los dientes resturados con postes de fibra de vidrio, bajo una carga compresiva de $550 \mathrm{~N}$, presentaron valores semejantes. El comporta- 
miento de los dientes restaurados con postes de fibra de vidrio fue similar al de los dientes naturales, mostrando una homogénea y más uniforme distribución del stress, y en esta investigación, presentaron una mejor performance biomecánica.

PALABRAS CLAVE: Poste de fibra de vidrio, poste de fibra de cuarzo, distribución de tensiones, método de elementos finitos.

\section{REFERENCES}

Adanir, N. \& Belli, S. Evaluation of different post lengths' effect on fracture resistance of a glass fiber post system. Eur. J. Dent., 2(1):23-8, 2008.

Barjau-Escribano, A.; Sancho-Bru, J. L.; Forner-Navarro, L.; Rodríguez-Cervantes, P. J.; Pérez-González, A. \& Sanchez-Marín, F. T. Influence of prefabricated post material on restored teeth: fracture strength and stress distribution. Oper. Dent., 31(1):47-54, 2006.

Craig, R. G. Restorative dental material. $6^{\text {th }}$ ed. St. Louis, C. V. Mosby, 1980. p. 60.

De Jager, N.; de Kler, M. \& van der Zel, J. M. The influence of different core material on the FEA-determined stress distribution in dental crowns. Dent. Mater., 22:234-42, 2006.

Eraslan, O.; Aykent, F.; Yücel, M. T. \& Akman, S. The finite element analysis of the effect of ferrule height on stress distribution at post-and-core-restored all-ceramic anterior crowns. Clin. Oral Invest., 13(2):223-7, 2009.

Eskitas,cıoǧlu, G.; Belli, S. \& Kalkan, M. Evaluation of two posts core systems using two different methods (fracture strengths test and a finite elemental stress analysis). J. Endod., 28(9):629-33, 2002.

Hayashi, M.; Takahashi, Y.; Imazato, S. \& Ebisu, S. Fracture resistance of pulpless teeth restored with post-cores and crowns. Dental Mater., 22(5):477-85, 2006.

Holmes, D. C.; Diaz-Arnold, A. M. \& Leary, J. M. Influence of post dimension on stress distribution in dentin. J. Prosth. Dent., 75:140-7, 1996.

Ko, C. C.; Chu, C. S.; Chung, K. H. \& Lee, M. C. Effects of posts on dentin stress distribution in pulpless teeth. $J$. Prosthet. Dent., 68:421-7, 1992.

Mannocci, F.; Ferrari, M. \& Watson, T. F. Intermittent loading of teeth restored using quartz fiber, carbon- quartz fiber, and zirconium dioxide ceramic rootcanl posts. J. Adhes. Dent., $1: 153-8,1999$.

Malferrari, S.; Mónaco, C. \& Scotti, R. Clinical evaluation of teeth restored with quartz-fiber reinforced epoxy resin posts. Int. J. Prosthont., 16(1):39-44, 2003.
Li, L. L.; Wang, Z. Y.; Bai, Z. C.; Mao, Y.; Gao, B.; Xin, H. T.; Zhou, B.; Zhang, Y. \& Liu, B. Three dimensional finite element analysis of weakened roots restored with different cements in combination with titanium alloy posts. Chin. Med. J., 119(4):305-11, 2006.

Lanza, A.; Aversa, R.; Rengo, S.; Apicella, D. \& Apicella, A. 3D FEA of cemented stell, glass and carbon posts in a maxillary incisor. Dent. Mater., 21:709-15,2005.

Pegoretti, A.; Frambri, L.; Zappini, G. \& Bianchetti, M. Finite element analysis of a glass fibre reinforced composite endodontic post. Biomaterials, 23:2667-82, 2002.

Pierrisnard, L.; Bohin, F.; Renault, P. \& Barquins, M. Coronoradicular reconstruction of pulpless teeth: a mechanical study using finite element analysis. J. Prosthet. Dent., 88:442-8, 2002.

Reeh, E. S.; Messer, H. H. \& Douglas, W. H.: Reduction in tooth stiffness as a result of endodontic and restorative procedures. J. Endod., 15:152-6, 1989.

Schillinburg, H. T. \& Kessler, J. C. Restoration of the endodontically treated tooth. Chicago, Quintessence, 1982.

Sorrentino, R.; Aversa, R.; Ferro, V.; Auriemmac, T.; Zaroned, F.; Ferrarib, M. \& Apicellaa, A. Three-dimensional finite element analysis of strain and stress distributions in endodontically treated maxillary central incisors restored with diferent post, core and crown materials. Dent Mater., 23(8):983-93, 2007.

Toksavul, S.; Zor, M.; Toman, M.; Güngör, M. A.; Nergiz, I. \& Artunç, C. Analysis of dentinal stress distribution of maxillary central incisors subjected to various posts and core applications. Oper. Dent., 31(1):89-96, 2006.

Zarone, F.; Sorrentino, R.; Apicella, D.; Valentino, B.; Ferrari, M. \& Aversa, R. Evaluation of the biomechanical behavior of maxillary central incisors restored by means of endocrowns compared to a natural tooth: a 3D static linear finite element análisis. Dent. Mater., 22:1035-44, 2006.

Zienkiewics, O. C. The Finite Element Method. London, McGraw Hill, 1986.

Correspondence to:

Dr Enrique Fernández Bodereau

Ituzaingó 1035

Córdoba

ARGENTINA

Email: laurabessone@hotmail.com bodereau@uolsinectis.com.ar

Received: 18-08-2010

Accepted: 19-10-2010 